
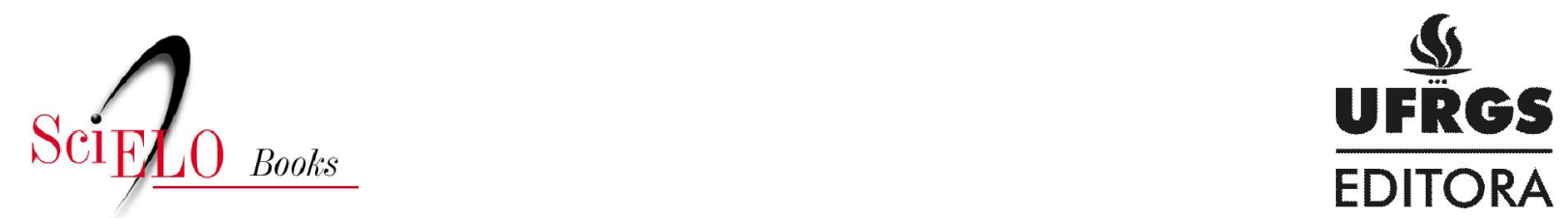

\title{
Apropriações da gramática democrática, perfis militantes e concepções de gestão pública (RS e MA)
}

\author{
Eliana Tavares dos Reis
}

\section{SciELO Books / SciELO Livros / SciELO Libros}

REIS, ET. Apropriações da gramática democrática, perfis militantes e concepções de gestão pública (RS e MA). In: MARENCO, A., org. Os eleitos: representação e carreiras políticas em democracias [online]. Porto Alegre: Editora da UFRGS, 2013, pp. 189-224. ISBN 978-85-386-0384-9. Available from doi: $10.7476 / 9788538603849$. Also available in ePUB from:

http://books.scielo.org/id/bfwrk/epub/marenco-9788538603849.epub.

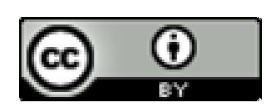

All the contents of this work, except where otherwise noted, is licensed under a Creative Commons Attribution 4.0 International license.

Todo o conteúdo deste trabalho, exceto quando houver ressalva, é publicado sob a licença Creative Commons Atribição 4.0.

Todo el contenido de esta obra, excepto donde se indique lo contrario, está bajo licencia de la licencia $\underline{\text { Creative Commons }}$ $\underline{\text { Reconocimento } 4.0 .}$. 


\section{Apropriações da gramática democrática, perfis militantes e concepções de gestão pública (RS e MA)}

Eliana Tavares dos Reis*

Nos mais diferentes cenários das lutas políticas contemporâneas é possível constatar, sobretudo nas últimas décadas, a afirmação de um "imperativo participativo" (Nonjon, 2005), a um só tempo, resultante e propulsor do trabalho de objetivação de um consenso em torno do ideal/ arranjo democrático. No presente capítulo pretende-se examinar dimensões que permitem apreender alguns fatores que condicionam o campo de possibilidades de ativação dessa gramática que fundamenta a edificação de modelos de gestão pública. Assim, as considerações que seguem fazem parte de uma reflexão mais ampla acerca dos mecanismos de produção de matrizes de referenciais e de práticas que se traduzem em experiências administrativas, mais ou menos bem sucedidas, que proclamam pautar-se por princípios de "participação", "cooperação", "articulação de setores e atores sociais diversos", laços de "solidariedade", "descentralização", etc. Ideias essas que contemplam demandas diversas e diversificadas, geralmente apontadas como propriamente e apropriadamente democráticas.

A discussão proposta se ampara em pesquisas centradas no exame das carreiras, destinos sociais e repertórios de mobilização de agentes que

Professora Adjunta do Departamento de Sociologia e Antropologia (Desoc) e do Programa de Pós-Graduação em Ciências Sociais (PPGCSoc) da Universidade Federal do Maranhão (UFMA). 
iniciaram sua militância durante o regime militar e, subsequentemente, ocuparam ou ocupam posições relativamente bem alocadas enquanto porta-vozes de diferentes "causas" em domínios sociais distintos, sobretudo políticos e universitários, no Rio Grande do Sul e no Maranhão. A investigação das duas configurações regionais pelo mesmo ponto de vista analítico e metodológico, bem como em função da utilização dos mesmos critérios mais gerais de delimitação do universo empírico (particularmente no que diz respeito ao estudo das entradas na política de agentes que participaram da "luta contra a ditadura"), inevitavelmente aciona o registro comparativo. Dentre as vantagens do confronto de lógicas e realidades contrastantes, vale destacar: a oportunidade de relativizar possíveis pré-noções ou "obviedades" que se constitui em um dos principais obstáculos ao trabalho do cientista social; a possibilidade de se encontrar regularidades, discrepâncias e especificidades dos condicionantes históricos, das correlações de forças políticas, dos perfis sociais, das trajetórias individuais e das problemáticas legítimas consagradas pelos agentes que estrearam sua atuação em conjunturas de crise política (Dobry, 2000); e ainda o valor propriamente heurístico do procedimento comparativo e do teste de referenciais de análise pertinentes para a apreensão dos universos em pauta.

A análise das dinâmicas permitiu trazer à tona questões sobre as diferentes formas de apropriação do discurso e de operacionalização prática do binômio "democracia" e "participação", que, evidentemente, variam conforme as especificidades nacionais, regionais, e, é claro, em função das arenas, dos objetos de disputas e das posições políticas e sociais ocupadas por seus porta-vozes. Mas que se coadunam, particularmente, em um "credo" que se impõe como prática e como representação (no duplo sentido) do mundo social, comportando espaços de atuação, bandeiras de luta, formas de mobilização, carreiras e perfis dos seus porta-vozes legítimos, etc.

Tendo isso em vista, a primeira parte deste texto é dedicada à reflexão/problematização mais geral em torno da afirmação do ideal democrático, da sua gramática e temática correlatas com poder de interpelar militantes e intelectuais preocupados com as "melhores alternativas" de governo popular; e a segunda parte é destinada à apresentação de alguns resultados de pesquisa que revelam as especificidades e consonâncias entre os casos investigados, mais diretamente no que diz respeito ao perfil e investimentos de militantes que constituíram equipes de governos, com experiências contestatórias e posicionamentos políticos semelhantes, no sentido de promover a "participação popular" nos dois estados (RS e MA). 
Alguns elementos da "moderna" gramática democrática

A afirmação da democracia como arranjo de governo e como crença é tributária de variados fatores normativos e cognitivos, sobretudo relacionados às formas práticas de funcionamento de governos representativos e à valorização de mecanismos considerados como eficazes para a "participação política do povo" ou para a reprodução/modificação das "elites no poder". Assim, nas suas diferentes versões (mais ou menos realistas ou idealistas), as atenções dos analistas sociais se voltam para questões que vão desde engenharia política melhor ajustadas às dinâmicas históricas até uma espécie de moral-cívica consagradora dos métodos democráticos. Passando ainda por aspectos da chamada "cultura política" ou considerando processos históricos de formação de Estados-Nação e suas especificidades (geralmente detectando-se nos "centros" as fontes de constituição das configurações bem sucedidas e atribuindo-se às "periferias" dificuldades de adequação relativamente fiel aos modelos centrais).

Um dos elementos comumente evocados para definir o sentido do jogo democrático é o da incerteza quanto aos seus resultados, em contraposição aos sistemas autoritários que se pautam pela circunscrição das ações e percepções dos indivíduos, procurando controlar os resultados dos seus movimentos (Dobry, 2000). Obviamente, nem os regimes democráticos são desprovidos de fundamentos de previsibilidade e certeza para a sua estabilidade e para alcançar o ideal da participação e renovação política; nem o ideal autoritário de antecipação das ações, com a limitação dos espaços, modalidades e repertórios de mobilização consegue ser atingido plenamente. Há perspectivas que assinalam que é justamente nisso que residiria a possibilidade de transformação de qualquer configuração histórica, ou seja, o modelo democrático poderia ser entendido como o resultado parcial e temporário de um estado de relações de poder, ou melhor, seriam atos de poder que constituem a objetividade social (Laclau, 1996; Mouffe, 2000).

De qualquer modo, a consolidação do arranjo e mito democrático (é bom que se diga, não sem contestações ao longo do tempo conforme os diferentes interesses em jogo nos principais contextos de sua emergência) fundamentou-se, em significativa medida, por sua capacidade de, por um lado, oferecer respostas e sentidos para aqueles que edificam e investem no jogo democrático. Por outro lado, por sua eficácia em controlar a agressividade social. A partir disso seria possível procurar contornar 
os obstáculos à apatia (o apolitismo) por meio da propagação de alternativas (reais ou imaginárias) resultantes do trabalho de mobilização de grupos e atores que explicitam a pluralidade compatível com a sociedade moderna. Do mesmo modo, seria possível conter os conflitos exacerbados (a politização excessiva) mediante a ênfase na busca por consenso passível de ser construído graças ao convívio regrado e o reconhecimento mútuo que sedimentaria esse arranjo (Braud, 1992).

No que diz respeito mais diretamente à afirmação da "democracia representativa", a principal característica apontada por Weber (1993) refere-se à progressiva especialização e profissionalização da atividade política. Nesta, os partidos políticos modernos assumem o lugar de destaque constituindo-se, como afirma Offerlé (1993), em empresas sistemáticas e coordenadas de conquista de poder político e também como veículos de defesa de causas de interesse dos "desfavorecidos" ou, simplesmente daqueles que estão fora da "política" (os "profanos").

É na articulação constitutiva de princípios políticos e jurídicos sob uma ideia de democracia como regime de governo fundado em crenças, que as eleições ocupam um lugar de destaque no universo de ritos e práticas cerimoniais, por um lado, interpelando profissionais de diferentes domínios sociais (jornalistas, advogados, cientistas sociais, etc.), afora os próprios "homens políticos" (Reis e Grill, 2010). E, por outro lado, assemelhando "todos os cidadãos no ato ficcional: a formação da vontade geral que transforma uma comunidade imaginada em 'realidade"' (Braud, 1997, p. 217). Deste modo, a concepção de cidadão estaria relacionada à exaltação do sufrágio universal e pode ser assimilada a um princípio fundamental da democracia em que o indivíduo seria capaz de ter uma opinião e de expressá-la em termos de preferências políticas e interesse pela esfera pública. A mobilização eleitoral, assim, assume contornos éticos, pois refletiria a imagem digna do "povo" como ente capaz de tomar decisões políticas e com o dever de estar ativados, enquanto "cidadãos" (indistintamente), no âmbito de suas instituições e de seus porta-vozes (Offerlé, 1993).

Sendo necessário construir consensos (ou ao menos "maiorias") no dissenso (a partir da pluralidade de posições), no "jardim das delícias democráticas", independentemente do tipo de democracia que se esteja falando (pluralista, representativa, participativa...), não há dúvidas de que um dos principais trunfos é o uso da linguagem. A disponibilidade para "debater" (que comporta a habilidade para "convencer"), objetiva-se 
como "categoria de conflito" e como trunfo por excelência, cujo principal objetivo é a imposição de princípios de classificação do mundo social. Então, numa ordem histórica em que confrontar pontos-de-vista é uma "forma de competência que pertence ao universo da lutas simbólicas" (em oposição aos combates físicos, por exemplo), o "debate de ideias" conquista centralidade como forma de "cultura democrática", tornando-se cada vez mais complexo, diversificando tanto os níveis e conteúdos articulados como os interlocutores envolvidos.

Nos desdobramentos das lógicas e práticas democráticas legítimas, além do debate entre os profissionais da política (fixação da "Assembleia" como lugar por excelência de deliberação), há cada vez mais a diversificação e multiplicação de categorias de profissionais aptos e autorizados a "debater" e sua expansão para agentes não necessariamente (ao menos em tese) especializados para tanto. Assim, a "participação popular" (idealmente, a de pessoas "comuns" interessadas nos assuntos "públicos" que lhes diriam respeito) nas tomadas de decisão é particularmente valorizada em algumas circunstâncias. A proliferação de vozes chamadas à cena é acompanhada pela redefinição dos espaços, institucionais ou não (instâncias, organizações, associações, fóruns, conselhos, etc.) pertinentes à manifestação dos múltiplos posicionamentos.

Com efeito, há a diversificação das modalidades de intervenção política que extrapola a atuação nos partidos políticos e sindicatos, (raramente sem estar em referencia a estes espaços "clássicos" de atuação), bem como das "causas" que conformam os repertórios de ação e dos perfis sociais dos agentes munidos de recursos e disposições para tomar a frente das "questões coletivas". O que conduz a refletir sobre as bases sociais do reconhecimento e das identificações entre os interlocutores, inseridos em diferentes arenas de disputa pela condução das deliberações. E ainda, é preciso considerar os condicionantes da inscrição dos agentes em um fundo comum de questões, condutas, recursos, princípios de autoridade e de autorização, que os individualiza em relação ao "cidadão anônimo" e redesenha as fronteiras entre o "porta-voz" e o "representado".

Assim, a gramática democrática passa a não comportar somente a "participação política" relacionada ao mercado político-eleitoral, mas se desdobra na reivindicação da necessária existência de outros lugares legítimos de inscrição do "cidadão" interessado em posicionar-se e, de algum modo, influenciar nas decisões do Estado, notadamente no que 
tange à implementação das suas políticas públicas percebidas como coletivamente apropriadas.

Dominique Memmi (1985) oferece a análise de como é constituído o campo de estudos que definem a "participação política" como uma representação normativa (e não um objeto de estudos) e um imperativo categórico (em detrimento da sua apreensão como resultado de processos históricos específicos); como uma norma que carrega a ambivalência de combinar obrigação e eficácia, fundamentada no "julgamento sobre a realidade da coisa e sobre o seu valor" (Dominique Memmi, p. 318, 1985); e como uma norma para a ciência política que, mesmo a partir de diferentes vias - passando pela problematização da "legitimidade da norma" - os politólogos fixaram-na como categoria fundamental de mensuração e prescrição do jogo político desejável. As concepções menos realistas (sobretudo aquelas que partem da separação dos "cidadãos politicamente ativos" dos "cidadãos politicamente passivos, nos termos weberianos) de democracia seriam forjadas na adição entre a "valorização da política" e a "representação das práticas políticas", tendo como um dos seus resultados mais radicais a concepção "hiperdemocrática": resistente ao sistema partidário e suas regras, defensora de formas alternativas de engajamento. De uma forma ou de outra, seria necessário levar em conta a multiplicidade de aspectos históricos e sociais, conjunturais e identitários, discursivos e práticos, que interferem tanto na valorização da "participação política" como na sua tradução em tomadas de posição sobre questões consideradas como legítimas e "políticas" ou "politizáveis".

\section{O valor democrático \\ e a "participação popular" no Brasil}

No Brasil, foi especialmente a partir do "regime militar" que os valores da democracia passaram a ser sistematicamente ressaltados e definidos com base na imbricação com outros modelos perseguidos por seus porta-vozes (principalmente, com versões de socialismo), sendo, paulatinamente, consubstanciados seus pilares inelutáveis. Neste caso, ideias e estratégias de ativação da "sociedade civil", da "participação popular", dos "movimentos sociais", entre outras, posicionaram-se no centro do debate político e acadêmico (com especial atenção das ciências humanas e sociais). ${ }^{1}$

1 Para Daniel Pécaut (1990), este "pensamento democrático" foi fundado na reativação da "sociedade civil: este é na verdade o lema que se difundirá no quadro de 
Na esteira do mesmo processo, foram edificados os espaços propícios para a inscrição (mobilização, socialização, hierarquização) de redes de militantes, compatíveis com a nova configuração social "democrática". Principalmente no decorrer dos anos 1980 e dos 1990 houve uma proliferação de associações e dinâmicas ebulientes da arena societária, viabilizando a atuação institucional dos agentes. Tendo se perpetuado como lugares legítimos de interlocução e deliberação de "lideranças democráticas", quase sempre esses canais de participação orientam seus debates e embates em torno da necessidade de formulação e efetivação de políticas públicas eficazes para as respectivas áreas ou temáticas que pretendem salvaguardar (Azevedo Moura e Silva, 2008; Avritzer e Navarro, 2003; Avritzer, 1997; Avritzer e Azevedo, 1994). Desta forma, as preocupações ao mesmo tempo normativas e acadêmicas acerca das "políticas públicas" e de modelos específicos, como o do Orçamento Participativo, assumem centralidade na agenda política e de pesquisas, principalmente, no âmbito das ciências humanas e sociais.

Arretche (2003, p. 07) situa os fatores conjunturais que incidiram nesse progressivo interesse:

O intenso processo de inovação e experimentação em programas governamentais - resultado em grande parte da competição eleitoral, da autonomia dos governos locais, bem como dos programas de reforma do Estado -, assim como as oportunidades abertas à participação nas mais diversas políticas setoriais - seja pelo acesso de segmentos tradicionalmente excluídos a cargos eletivos, seja por inúmeras novas modalidades de representação de interesses - despertaram não apenas uma enorme curiosidade sobre os "micro" mecanismos de funcionamento do Estado brasileiro, como também revelaram o grande desconhecimento sobre sua operação e impacto efetivo.

O problema é que os trabalhos sobre as "políticas públicas" raramente atentam para a relação condicionante e condicionada entre as repre-

abertura. Ele não comporta quaisquer concessões ao liberalismo ou exaltações à democracia formal" (p. 290, 1990). A ordem naquele momento era institucionalizar o dissenso, por uma ação sustentada em um realismo pragmático em detrimento das práticas revolucionárias, essas últimas desvalorizadas pela estratégia dos militares de definir o "golpe de 64" como uma "revolução", apresentando um deslocamento da significação política da palavra (Fontes, p. 232, 1996). Conforme Fontes (1996), apenas com a mobilização dos movimentos sociais no fim da década de 1970 é que ocorrerá a revalorização da ideia de "revolução". 
sentações e características sociais dos agentes envolvidos na formulação de políticas, bem como os contextos históricos e de disputas políticas nos quais estão inseridos. Essas são dimensões explicativas das opções de políticas priorizadas ou descartadas, interferindo não somente nas estratégias e escolhas assumidas nos processos decisionais como nos efeitos que podem acarretar. A política pública deixa de ser tomada apenas como processo e causa, e passa a ser considerada como efeito de processos históricos e sociais mais amplos que definem o espaço das questões e dos procedimentos possíveis e legítimos.

Nesse sentido, cabe operar uma ruptura com as definições nativas dos militantes e do senso comum intelectual que consideram os objetos de disputa das políticas públicas como "interesses" pré-existentes de "grupos" dados, com maior ou menor "influência" sobre as arenas de decisão. Para tanto, é necessário dar conta dos múltiplos processos e atores que fazem o grupo existir enquanto força política, observando a demarcação de fronteiras e clivagens que estabelecem com os concorrentes. Sem deixar de mencionar os trunfos individuais dos protagonistas e os recursos coletivos das organizações a que pertencem, bem como os repertórios que acionam: manifestações; abaixo-assinados; colóquios como fóruns, congressos, eventos e os registros de expertise e negociação; mobilizações nos bastidores da cena política e nas redes de sociabilidade próprias aos segmentos dominantes. Desse modo, desenha-se um intrincado quadro de relações sociais e políticas, de agentes pertencentes a distintos domínios sociais, de definição e usos de interesses, de trânsitos, interstícios e mediadores entre setores estatais e não-estatais com suas respectivas bases materiais e simbólicas (Offerlé, 2009, 1998; Coradini, 2008).

A afirmação de novas temáticas, atores e lugares de intervenção produziram, dessa forma, deslocamentos nas fronteiras já tênues entre domínios políticos, intelectuais e sociais, das exigências para a circulação entre eles e das definições de problemas sociais considerados legítimos e, por isso, potencialmente constituídos como questões políticas relevantes. Sendo assim, o terreno em pauta é marcado pela plasticidade de posições e posicionamentos mais ou menos militantes, intelectuais ou administrativas, permitindo que, em muitos casos, sejam os mesmos agentes que, em diferentes momentos, ocupem as diversas posições de reivindicação, de fundamentação teórica, de deliberação, de formulação e de operacionalização. Neste caso, os modelos de gestão pública valorizados e/ 
ou implementados seriam o resultados da confluência entre, de um lado, princípios e discursos compartilhados e, de outro lado, saberes, técnicas, linguagens, códigos, redes de relações, etc. acumulados nas variadas inserções, constituindo o background e a certificação de competência de alguns agentes para a ocupação de posições relativamente bem alocadas no âmbito governamental, na "sociedade civil", ou na universidade, por exemplo; de qualquer modo, como porta-vozes das questões que ajudam a edificar.

Nicolas Gilhot (2003) propôs uma análise dos "profissionais da democracia" indicando a hegemonia norte-americana na exportação para o "terceiro-mundo" de concepções e modelos de Estado e de democracia. O foco da sua discussão são as lógicas da expansão da indústria de promoção dos direitos humanos e dos processos de democratização desde Washington, que resultaram na reconversão de militantes antiimperialistas (muitos dos que "lutaram contra a ditadura"), em experts do Estado. Isso graças às estratégias de gestão de programas internacionais fixados por esse centro que financiou os mais variados investimentos de "formulação", possibilitando que agentes com determinados "perfis" profissionais e capital militante, acionassem seus saberes de perícia e de conhecimento de causa no elogio à democracia e aos direitos humanos, sobretudo na conquista de posições de destaque em diferentes domínios sociais. O que, por sua vez, seria uma garantia da própria sustentação dos discursos e contradições das políticas de Estado americano. Nasceriam, assim, os "profissionais da democratização", "beneficiários" de investimentos econômicos e institucionais que, posteriormente, se constituíram como consultores, membros de ONGs, de centros de pesquisas universitários, de associações profissionais; etc. Dentre eles, estariam muitos politólogos que se serviram da caução científica para coadunar seus estudos sobre as "transições democráticas" (sobretudo na America Latina) com a agenda "global".

É claro que não é possível demonstrar a conexão direta entre esses fatores e a constituição dos discursos e prática aqui tratadas, e é claro, também, que ele tem alguma interferência, assim como outros, na conformação dos repertórios de mobilização e das modalidades de "participação política" perseguidas pelos diferentes agentes, no Brasil.

Outra possível interferência importante seria aquela advinda da multiplicação de movimentos reivindicatórios que se ergueram em diferentes contextos nos anos 1960 e que, em consonância, promoveram uma "subversão cognitiva" das bases de esquerda, conforme examinado por 
Gilcher-Holtey (2009). Com características distintas, porém com "raízes europeias" (mais diretamente o "maio de 68"), ela parte da caracterização dos anos 1960 como um "momento crítico", tendo sido oportunizado pela "crise estrutural das universidades" e, na cena internacional, pelas interpelações da guerra do Vietnã. Conjugam-se a isso, os princípios de democratização e o crescimento das modalidades de participação que aparecem como uma retomada das propostas da Primavera de Praga, ativando "ideias força" como "democracia participativa", "autogestão", "codecisão" ou "paridade", contribuindo, assim, para a subversão das percepções em voga acerca do mundo social e a formação de uma "nova esquerda intelectual' (Gilcher-Holtey, p. 185, 2009).

Para a presente discussão, importa, acima de tudo, situar a centralidade da "participação popular" acionada como bandeira de luta legitimadora de práticas concebidas como "democráticas", constituindo-se como objeto de conflitos em torno dos mecanismos mais eficazes para proporcioná-la, o que significa do mesmo modo, ou fundamentalmente, a luta pelo reconhecimento daqueles que estariam mais aptos para tanto.

As propostas e avaliações da institucionalização dos "conselhos" ocuparam a agenda de debates de militantes e intelectuais preocupados com a elaboração e aperfeiçoamento de programas voltados para a aplicação de recursos públicos, sendo que as áreas priorizadas por parte do orçamento poderiam ser definidas com a participação da população nas tomadas de decisão (Gandin, 1994). Uma dessas "experiências" de gestão "democrática e participativa" do orçamento público é o Orçamento Participativo. Este se afirmou como arranjo institucional sui generis que articularia a democracia representativa e a democracia participativa numa "inovação democrática", cuja eficácia seria comprovada na sua aplicação não somente em muitos municípios brasileiros, como também por sua exportação para cidades da Europa e da América Latina (Avritzer e Navarro, 2003).

Na genealogia eventualmente evocada desse mecanismo, são resgatados os casos da administração em Lages (SC), em Vila Velha (ES) e em Pelotas (RS), ainda durante o regime militar, o que seria uma explicação para não terem sido bem sucedidas na sua continuidade, ou seja, havia limitações nas condições históricas e conjunturais de sua realização; afora outras iniciativas de descentralização administrativa em São Paulo, Rio de Janeiro, Recife, entre outras, anteriores à consagração do Orçamento Participativo no Rio Grande do Sul (Souza, 2000), decorrente dos 
dezesseis anos de administração do Partido dos Trabalhadores à frente da prefeitura de Porto Alegre. É preciso ressaltar também a miríade de trabalhos escritos de caráter laudatório, contestatório ou analítico, somando-os às repercussões internacionais muito tributárias da realização do Fórum Social Mundial nesta capital, tudo confluindo para a objetivação da "experiência" como a mais significativa e mais ou menos eficaz de gestão "participativa e popular".

\section{Porta-vozes da "participação popular"}

O principal material que serviu de base para a produção deste texto é proveniente de pesquisas mais amplas sobre os condicionantes históricos e sociais das modalidades, espaços e repertórios de intervenção política no RS e no MA, abordando as carreiras sociais, políticas e profissionais de agentes que estrearam sua atuação em movimentos de resistência à ditadura militar nos dois estados. No âmbito destes investimentos, foram produzidas reflexões mais específicas acerca da afirmação da "participação popular" na "gestão pública" do Rio Grande do Sul como "causa legítima" e sobre os porta-vozes da cultura, os condicionantes do trabalho de mediação cultural e de produção de referenciais de políticas públicas no Maranhão.

No primeiro caso, o alvo é o Orçamento Participativo, operacionalizado por membros do Partido dos Trabalhadores, com ênfase na potencialização ou aperfeiçoamento de um modelo de "democracia representativa", mediante o aprofundamento de mecanismos de participação e decisão orçamentária. Foram observados aspectos divergentes e semelhantes entre agentes que se apresentam como antagonistas no espectro de força políticas do estado, responsáveis por sua edificação, a partir das lutas travadas por sua definição, paternidade e operacionalização (Reis, 2008a). No segundo caso, é examinada a gestão da "cultura" por uma equipe constituída predominantemente por componentes vinculados ao PT, durante a administração do Partido Democrático Trabalhista no governo do Maranhão (2007-2009). Como o anterior, o olhar é direcionado não apenas para os aspectos discrepantes como também para as características homogeneizantes do universo de representações e posicionamentos de agentes localizados em lados opostos no espaço de luta política.

No Rio Grande do Sul, os porta-vozes da "participação popular" investigados apresentaram distinções no que tange aos seus perfis sociais, às orientações ideológicas e aos pertencimentos a siglas partidárias (no- 
tadamente, o PMDB e PPS, PT e PDT). Dentre as semelhanças, pode-se ressaltar a estréia de sua atuação política nos movimentos de resistência ao regime militar; a participação em eventos e discussões, já no final da década de 1970, que o salientavam como alternativa às praticas e concepções "populistas", "tradicionais", "conservadoras", etc. de política; a premência na elaboração e implantação de mecanismo da "participação popular"; e a exaltação de "modelos" de "gestão" estruturados sobre a mesma base (a "participação popular"), mesmo que com referenciais contrastantes (mais ou menos militantes ou técnicos; com origens mais ou menos comunistas ou cristãs; etc.).

Sobre esse último ponto, cabe realçar que as divergências referentes às forças políticas em oposição no RS se cristalizaram nas concepções de OP e Governança Solidária. De um lado, o "Orçamento Participativo" seria um modelo fundado na discussão do orçamento público, no caráter decisional e no aprofundamento dos mecanismos de participação (como resposta aos limites da democracia representativa). De outro lado, a "Governança Solidária" apresentava-se como uma alternativa, mais ampla e abrangendo o próprio "OP”, alicerçada em valores como solidariedade, cooperação e parcerias decorrentes do "compartilhar de espaços de convivência” (Reis, 2008a e Coradini, 2002).

No entanto, nem sempre a ideia de "participação" se impõe como objeto de luta por parte de diferentes equipes administrativas. Há configurações regionais em que, antes disso, ela (como as noções de "democracia", "cidadania", "sociedade civil", etc.) constitui-se precariamente nas tentativas de interpelação de determinados setores sociais. Tal fragilidade pode estar relacionada a basicamente três fatores mais amplos: as características das histórias regionais e das práticas políticas específicas em que a consolidação de outros elementos (como a "tradição", a religiosidade, a "políticas das reciprocidades"....) exigem que os mesmos estejam articulados nas cadeias de equivalências construídas pelos porta-vozes; as discrepâncias geracionais entre os agentes e "grupos" que compõe o espaço político e que ocupam as principais posições de mando; e, o grande desequilíbrio na correlação de forças com explícito benefício das posições e posicionamentos gestados em configurações discrepantes daquelas em que ocorreram as inserções em nome das chamadas "lutas democráticas".

É possível afirmar que as gerações de militantes que se inscreveram em ações de contestação ao regime militar são muito mais atraídas e 
seus protagonistas apresentam-se como autorizados a apropriar-se do discurso democrático. Acrescenta-se a isso, que essa tendência aumenta quando esses agentes inauguraram a sua atuação política naqueles movimentos e que, por esse motivo, estiveram (pela atuação em movimentos de resistências, devido à formação universitária, por assimilação das formulações disseminadas por intelectuais de notoriedade nacional, etc.) mais expostos a essas ideias e ideais. Neste caso, os repertórios e práticas são muito mais estruturantes da gramática política em dinâmicas em que os militantes passaram, posteriormente, a ocupar lugares de relativo destaque seja no domínio político, seja no universitário, sindical, etc. do que em dinâmicas em que isso não ocorreu. De qualquer modo, mesmo nesses casos, algumas constâncias podem ser percebidas.

Trata-se, então, de observar os investimentos de determinados agentes num discurso que notabiliza os modelos de "democracia" e de "participação" política como ressonância de "experiências" tidas como relativamente "bem-sucedidas". Para delimitar melhor essa questão, propõe-se tomar especificamente a defesa de determinados mecanismos de "políticas públicas" para a "cultura" no Maranhão, conduzida por uma rede de militantes que veio a formar a equipe de governo, nesta área, durante a administração estadual do pedetista Jackson Lago. ${ }^{2}$

Esta última opção pode ser duplamente justificada pelo fato de que, em primeiro lugar, a "cultura" é uma "causa" que se constituiu como legítima no estado, definida nos embates acadêmicos, assimilada no senso comum, racionalizada nas políticas de Estado e que ocupa um lugar de destaque na construção da identidade regional e das múltiplas identidades específicas (Reis, 2011). E, em segundo lugar, porque os debates e embates em torno da definição da "cultura" e de políticas públicas apropriadas, permite ponderar sobre disputas mais abrangentes e princípios subjacentes à dinâmica política e social regional. As polêmicas que animam o meio universitário, confrontos, arranjos e negociações político-institucionais em diferentes governos, a participação da chamada "sociedade civil" ou da "cultura popular" em determinados espaços propícios e propiciados para a discussão da "cultura" e do "cultural" no Maranhão,

2 Jackson Lago (PDT) venceu as eleições de 2006, apoiado por um amplo e heterogêneo leque de alianças construído com a finalidade de derrotar a "família Sarney". Entre os seus aliados na campanha e quadros do governo contou com militantes de partidos de esquerda no estado como o PT. 
são reveladores da configuração dos objetos e objetivos compartilhados, disputados e distintivos entre os porta-vozes da "cultura".

Algumas considerações sobre essa dinâmica são importantes. Com base no estudo de maior fôlego, atentou-se para a existência de uma polaridade (relativamente recorrente) entre o que seria uma perspectiva mais "empresarial" e outra mais "militante" entre o pessoal político administrativo das gestões do governo do estado do Maranhão, comandadas pelos principais antagonistas das últimas décadas: Roseana Sarney (PMDB) e o agora falecido Jackson Lago (PDT), cujos cortes discursivos que procuram imprimir expressam-se na oposição: modernizadora $\mathrm{X}$ democrática, respectivamente.

De um lado, "racionalização", "modernização", organização e maximização do trabalho de produção, sanção e divulgação dos bens culturais, num discurso "para fora", visando o mercado externo, com a promoção do estado e dos seus personagens. Neste caso, o desenho de uma engrenagem de laços de tipos variados que se ramificam verticalmente e horizontalmente, abrangendo agentes com perfis e posições sociais diversos, assim como os lugares nos quais se inscrevem, apropriados à divisão social do trabalho de consagração das representações e dos representantes legítimos da "cultura". De outro lado, "participação", "democratização", "descentralização", a produção cultural devendo ser "beneficiada" e "vivenciada", num discurso voltado "para dentro", visando o mercado interno, com a busca de uma gestão "meritória" das políticas culturais e garantindo a "espontaneidade" das manifestações culturais. Em outros termos, a ativação do repertório sancionado na gramática democrática universalista (em nome da "sociedade civil", da "cidadania", "ética", etc.). Nesse caso, as redes de relações configuram uma maior horizontalidade (o que não significa dizer que não existam egos centralizadores de laços ${ }^{3}$ ) e os domínios de inscrição são heterogêneos e maios simétricos em termos de força política. Como se vê esse espaço foi privilegiado para a emergência de um discurso participativo e para a afirmação de seus porta-vozes.

Porém, para além das rivalidades partidárias, efêmeras e voláteis, revela-se neste espaço de concorrência a cristalização de teias de indivíduos que se encontram espraiados em domínios da cultura (teatro, música,

3 Sobre as definições e potencialidades analíticas dos estudos de redes, ver Mayer (1987) e Landé (1977). 
dança, etc.) e que se reúnem em lugares e meios de expressão ("grupos", instituições governamentais e universitárias, publicações, etc.). A partir deles, alimentam, renovam, tecem, redefinem e fixam momentaneamente lealdades, hostilidades, e retiram gratificações materiais e simbólicas. No interior dessas cadeias de agentes, competências políticas e técnicas mesclam-se numa arena de disputas por postos em governos e por reputação social. Um paradoxo se estabelece: a combinação da valorização dos porta-vozes da cultura na chamada "sociedade" e a posição periférica e via cooptação no espaço político.

Como resultado, a oposição (que se mistura e é diretamente dependente dos alinhamentos políticos) entre agentes que falam "em nome da cultura", amparados na autoridade de títulos escolares e profissionais e na posse de biografias de inserções em múltiplos espaços. O que os difere, porém, não são nem as competências, nem os domínios de atuação, mas, principalmente, o lugar ocupado pelas personalidades e pelas instâncias de consagração as quais estão vinculados. Em outros termos, o valor tanto dos indivíduos quanto dos lugares a partir dos quais falam se mostram profundamente dependentes dos resultados das disputas eleitorais, que, por sua vez, tem mostrado um forte desequilíbrio na balança do poder (Elias, 1999), pendendo para um dos pólos antagônicos que estruturam a dinâmica política mais ampla.

\section{Traços gerais da morfologia} dos militantes da "causa participativa"

As indicações sobre a caracterização geral dos universos considerados são primordiais para fundamentar as condições de afirmação de porta-vozes e de "causas" legítimas relacionadas à griffe democrática sob determinadas circunstâncias históricas e regionais. Assim, na primeira parte da discussão que segue, as considerações vão ser desdobradas tomando-se quatro eixos fundamentais, quais sejam: 1) os perfis sociais dos agentes; 2) as modalidades de atuação militante durante o "regime militar"; 3) seus destinos, principalmente em termos políticos; e 4) os investimentos visando a implementação de formas "participativas" e "populares" de "democracia". E, na sequência, a pretensão é de dar algumas pistas sobre as diferentes condições de apropriação dessas ideias referenciadas em concepções que guiam e justificam a adesão a determinados discursos e formas de gestão. 
A partir da análise dos quatro eixos supracitados, observou-se a sempre maior diversificação de possibilidades para o caso "gaúcho", quando cotejado ao caso maranhense.

No que concerne aos perfis sociais, atentou-se que são mais heterogêneos para o RS e menos para os militantes do MA. Um indicador desse aspecto é aquele referente aos investimentos em escolarização que, no que pese os dados analisados para os dois estados revelarem que são semelhantes, para o primeiro observou-se uma maior diversificação das instituições de ensino, dos cursos universitários realizados e das profissões seguidas; ao passo que, para o segundo, há uma concentração em instituições localizadas na capital, frequentadas desde o ensino primário, e nas universidades Federal e Estadual do estado, nas quais fizeram mais predominantemente cursos voltados para a área de ciências humanas. ${ }^{4}$

No RS, os militantes são filhos da chamada classe média, basicamente os pais são funcionários públicos, professores universitários, militares, alguns profissionais liberais, comerciantes, entre outros. Grifa-se o peso relativamente alto do capital cultural e político de origem, isto é, são provenientes de famílias que valorizaram a prática, notadamente, da leitura e de viagens, bem como sublinham algum tipo de adesão, atuação ou concepção de política definida. Enquanto no MA, os militantes são originários de uma extração mais baixa da classe média, isto é, são filhos de funcionários públicos, muitos trabalhadores manuais, autônomos, operários e pequenos comerciantes, raramente com algum tipo de atuação política sistemática. Esses agentes valorizam e têm, na sua maioria, vínculos com a "cultura" enquanto forma de expressão artística e, portanto, dedicam-se de diferentes formas a essa dimensão, não necessariamente como aquisição de um capital tido como legítimo, mas como produtores (músicos, compositores, teatrólogos, atuando no teatral, literatos, entre outros), situando-se na "tradição cultural" do Estado, definidor da identidade regional.

No que diz respeito às formas de mobilização durante a "ditadura", no RS estas foram deflagradas tanto na capital (Porto Alegre) como no interior do estado e foram relativamente intensas durante as décadas de 1960, 70 e 80. Evidentemente, tendo sido modificadas, ao longo desse período, os personagens, as temáticas priorizadas, as justificativas acio-

4 Fatores estes que pesam igualmente para a seleção de Deputados Federais, como demonstrou Grill (2008). 
nadas, os tipos de intervenção e o fluxo de entrada de novos aderentes no trabalho de resistência.

$\mathrm{Na}$ "luta contra a ditadura", entre outras estratégias, foram realizadas passeatas, produção de panfletos, reuniões, treinamentos de guerrilha, atuação nas organizações clandestinas articuladas nacionalmente, exílios como extensão da "luta", participação, sobretudo a partir da segunda metade dos anos 1970, nos marcos do Movimento Democrático Brasileiro (MDB) e nos debates sobre a articulação de partidos políticos, vislumbrando o pluripartidarismo. Destaca-se, em especial: 1) a forte importância da mobilização estudantil secundarista, mas principalmente na universidade; 2) o peso significativo das organizações clandestinas na articulação dos agentes e das "ações"; e 3) a inscrição protagonista no MDB, particularmente mediante canais como o Setor Jovem e o Instituto de Estudos Políticos Econômicos e Sociais (Iepes).

No interior do estado, observou-se a considerável influência da Igreja na atuação de jovens que entraram em grupos católicos e, sob os investimentos da Ação Católica, participaram, por exemplo, da Juventude Universitária Católica que, combinada com as pautas esquerdistas mais amplas de "combate à ditadura", constituíra a Ação Popular (AP) que, de modo muito simplificado, foi a organização política dos "jovens católicos" fora da égide da Igreja.

Essas inserções favoreceram a vinculação dos militantes em grupos um tanto coesos, com características sociais mais ou menos semelhantes que se deslocaram, no decorrer de suas trajetórias coletivas, com relativa sintonia. Estes grupos (de fronteiras e unidades móveis) aliaram-se em determinadas circunstâncias de "luta contra a ditadura", localizando-se no espectro das forças esquerdistas, marxistas, socialistas, revolucionárias, etc.; aproximaram-se de dirigentes estabelecidos no campo oposicionista construindo vínculos (ideológicos, afetivos, instrumentais, etc., conforme o caso); rivalizaram com as lideranças políticas estabelecidas e também entre si, disputando modelos de socialismo, de luta revolucionária, de organização partidária, de formas legítimas de gestão (já na "era democrática"), etc. Desfrutando, muitos deles, posições de notoriedade política no RS e no plano nacional, principalmente, reconfigurando o espaço das intervenções políticas no estado (Reis, 2008b; 2007).

Para o estado do Maranhão a pesquisa ainda está em fase de andamento, no entanto já é possível lançar algumas indicações. No que tange 
a atuação política de militantes que lutaram contra a ditadura, observa-se que esta foi muito mais centrada na capital (São Luís) e que teve seu período mais intenso nos anos 1970 e 1980. Neste caso, o peso maior recai sobre o trabalho de mobilização realizado por lideranças da igreja católica, não raro provenientes de países da Europa (como Itália e Bélgica) - empenhados, desde os anos 1960, no atendimento e organização de populações do chamado "terceiro-mundo" - que agiram via movimentos de base e conquistaram uma presença preponderante na articulação das problemáticas legítimas no estado.

Assim, por um lado, a organização do movimento estudantil, fundamentalmente no âmbito universitário, que conseguiu alguma notabilidade nos desdobramentos subsequentes, foi decorrente do engajamento de militantes que mantinham elos com lideranças deste universo religioso, geralmente filiadas a versões politizadas e heterônomas da Igreja, mormente a Teologia da Libertação.

A atuação mais contundente em organizações clandestinas ligada à luta armada e acionada nas reconstituições retrospectivas foi "rural", tendo à frente Manoel da Conceição, reconhecido como o líder camponês, com atuação sindical, experiência de exílio em Genebra, fundador do PT, tendo concorrido, em 2000, a presidente deste partido. Em sua biografia são geralmente enfatizadas a origem pobre e a deficiência para andar decorrente dos tiros que levou nos pés pela polícia numa situação de confronto ainda durante o regime militar (Fiuza, 2005, p. 53). Vale destacar a interferência da inserção religiosa no seu itinerário, por exemplo, como auxiliar de pastor e na realização participação no Movimento de Educação de Base (MEB), organismo da Conferência Nacional dos Bispos (CNBB), constituído em 1961, para a "educação popular em diversas regiões do Norte e Nordeste do país", por serem regiões "em que os indicadores socioeconômicos revelam situação de pobreza e, consequentemente, índices sociais e econômicos abaixo dos desejados" (http://www. meb.org.br, acessado em 16/05/2011).

Afora isso, alguns protestos foram marcantes na história de contestações maranhenses e na afirmação de porta-vozes, de instâncias e de questões legítimas no estado, tais como as "lutas por moradia", aquelas em torno dos "direitos humanos", o "movimento contra a carestia", a "greve da meia passagem". Em pesquisas monográficas específicas que vem sendo feitas sobre essas mobilizações, os repertórios e perfis dos 
militantes, tem-se observado a importância dos movimentos de cunho "cultural" no papel de produção (ou reprodução) de princípios éticos e estéticos indissociavelmente políticos, religiosos e culturais.

O exame das lógicas de inscrição nesses lugares, repertórios e protagonistas, bem como seus desdobramentos posteriores, permitiu identificar a existência de uma maior densidade de interconhecimentos e inter-reconhecimentos, com a constituição de redes mais flexíveis de relações. Isto quer dizer, em que os laços de amizades, por exemplo, podem ser mais ou menos duradouros, entretanto aqueles que definem o pertencimento a determinadas organizações são mais efêmeros, inconstantes, tributários da trama de posicionamentos e oportunidades em constante movimento neste cenário.

No tocante aos destinos dos agentes e o empenho na operacionalização da "participação popular", mais prontamente no que se refere às posições que ocupam na hierarquia do espaço social e político das configurações em questão, detectou-se o "sucesso" de muitos militantes gaúchos na conquista de lugares de destaque em domínios políticos e universitários locais e nacionais. A inserção no MDB parece ter sido significativa na disputa geracional com dirigentes políticos estabelecidos, desvendando as estratégias das jovens lideranças no sentido de impor percepções e formas de agir políticas alternativas. Contaram com saberes herdados sobre o "mundo político" (muitos oriundos de famílias com algum tipo de inscrição política, principalmente de orientação "comunista" ou "trabalhista") e como saberes adquiridos (transmitidos no mundo acadêmico e interpretações do marxismo) que compunham o instrumental de intervenção potente. No mesmo sentido, se distinguiram entre si em termos de disputas pela ocupação de posições de porta-vozes da "esquerda democrática", dos seus símbolos, siglas e iniciativas.

Esses aspectos contribuíram para a constituição de uma nova sigla partidária forte (PT), mas também a presença de lideranças nascidas da "luta contra a ditadura" em partidos comandados por "chefes políticos tradicionais", como o PDT e o PMDB. Para esses últimos, o confronto geracional no âmbito desses partidos promoveu a flexibilização do poder das posições e posicionamentos dominantes e repercutiu numa relativa aproximação de perfis e bandeiras de luta daqueles militantes petistas. Gerando, portanto, a reconfiguração do espaço das relações de força no RS.

É claro que isso não significa dizer que partidos e lideranças sejam pouco distintos. Os perfis específicos dos militantes são diferentes e apre- 
sentam encaminhamentos políticos discrepantes, no entanto essas agremiações possuem um mesmo repertório de problemática, um mesmo espaço semântico a partir do qual se distinguem. Por exemplo, com relação à valorização da "participação popular" como uma "causa legítima" nos três principais partidos (PDT, PT e PMDB) que visaram empreender e consagrar a forma mais eficaz de gestão pública "democrática", "participativa" e "popular": via Coredes, Orçamento Participativo e Governança Solidária, respectivamente.

No Maranhão, observa-se que o ingresso nos movimentos de contestação ao regime militar é mais tímido e mediado por princípios religiosos. A atuação no MDB é relativamente fraca, até porque as fronteiras partidárias são mais bem guardadas pelos chefes políticos locais, obstruindo a possibilidade de emergência de um luta geracional intensa pela imposição de princípios de política e de sociedade inovadores. O próprio Partido dos Trabalhadores, que aparece do mesmo modo como aglutinador de opções alternativas e vinculado às lutas políticas democráticas e de esquerda, se apresenta como uma organização com pouca força política, enquanto o PDT e o PMDB são dominados por lideranças construídas em outras bases e experiências políticas.

A especialização militante ocorre com bastante força via universidade, mas sem usufruir de posições de muito destaque nessa esfera e com forte interferência da igreja e dos chamados "movimentos sociais". De um modo geral, os militantes examinados ocupam posições dominadas não somente no espaço político mais amplo como também nos universitários e, na clivagem que parte os embates no estado em "oligarcas" e "antioligarquias", constituem o espaço específico de produção dessas oposições. ${ }^{5}$ Evidencia-se uma fraca especialização da esfera eleitoral e da dimensão técnica no âmbito administrativo.

Por todos esses motivos, verifica-se a maior vulnerabilidade das apropriações da gramática democrática e precárias tentativas de operacionalização de política públicas nesse sentido. Os agentes falam em nome da "participação popular" e criam lugares de debate em torno das temáticas democráticas aplicadas à "realidade" do estado: fóruns, semi-

5 Sobre a dinâmica de produção da categoria "oligarquia" e seus usos em batalhas políticas e intelectuais, ver Grill (2010). 
nários, conselhos, etc. Entretanto, veem seus investimentos frustrados pela preponderância de lógicas patrimoniais e faccionais por eles mesmos identificados nos seus próprios meios de inscrição.

\section{Carreiras exemplares \\ e concepções de gestão pública}

As mesmas dimensões de análise que foram estabelecidas para situar o perfil geral dos agentes investigados orientaram a apresentação que segue de itinerários exemplares com o intuito de demonstrar de modo um pouco mais preciso a articulação dinâmica entre elas. Optou-se então por tomar dois casos de lideranças que, além de contar com posições autorizadas de formulação e enunciação do OP no RS e da "cultura" no MA, possuem propriedades sociais e inscrições políticas representativas dos militantes contemplados nas respectivas configurações. Tendo em vista o que foi discutido até aqui, as descrições subsequentes ilustram dois casos de emergência da "causa" a partir dos protagonistas.

Filho de médios proprietários rurais, Ubiratan de Souza, ao apresentar a inserção partidária do pai em entrevista, ressalta a ideia de que ele fora membro, assim como outros familiares, do "antigo" Partido Trabalhista Brasileiro (PTB), agremiação que se caracterizaria pela "inserção social", "anti-imperialista" e voltada para a "soberania nacional" e não uma "legenda de aluguel", como seria atualmente. Além dessa "influência", é destacada também a do irmão mais velho, que fora seu contemporâneo de movimento estudantil (presidente do centro acadêmico da faculdade de direito da UFRGS em 1968 e posteriormente deputado estadual).

A liderança em questão inaugurou sua atuação no movimento estudantil secundarista, em Cachoeira do Sul (município do RS), depois de 1964. Na passagem que segue, ele sublinha o contato inicial com o "grupo" de militantes secundaristas, os "Brancaleones", e com "velhos comunistas", bem como buscar demonstrar sua "politização" precoce via o acesso a uma "literatura" condizente com suas perspectivas de "militância":

O nosso o primeiro contato nosso lá de Cachoeira é com o pessoal dos Brancaleones, apesar e também com o pessoal do Partido Comunista que eram mais velhos que a gente, não era a mesma geração. Então, já em Cachoeira, a gente já tinha uma politização, já tínhamos lido inclusive uma literatura, como "Os 10 dias que abalaram o mundo" com John Reed, "A história da riqueza do homem" do Léo Huberman, já naquela época né?! E, depois os li- 
vros do Che, "O diário da luta" do Che, "A guerra de guerrilhas", aí também livros do Lênin, do Stalin, do 'O que fazer'.

O deslocamento para Porto Alegre para concluir o $3^{\circ}$ científico na escola Pio XII teria sido a oportunidade de "aprofundar a militância e a literatura também". Já havia um contato prévio com militantes do colégio Júlio de Castilhos, basicamente os membros do "grupo" chamado "brancaleones". Tratava-se de um conjunto de estudantes secundaristas dissidentes do PCB que, posteriormente, veio a se constituir como base de apoio e como uma das interconexões fundadas em relações pessoais e ideológicas do casal Carlos Araújo - que fora deputado estadual e candidato a prefeito de Porto Alegre pelo PDT -; e Dilma Rousseff - que ocupou secretarias do estado no governo de Alceu Collares do PDT e de Olívio Dutra do PT, foi ministra-chefe da casa civil no governo de Luís Inácio Lula da Silva do PT, atualmente é a Presidenta da República (Reis, 2008b, 2007).

Uma das características desse "grupo" era a disposição para o ativismo e para as "ações armadas". Dentre os que foram estudados (Reis, 2008c; 2007), a maioria possuía uma origem social relativamente baixa, com pais operários, ferroviários, pequenos comerciantes, com inserção sindical e baixa escolaridade. Eles apresentam como característica particular do seu ingresso na militância a vinculação original ao PCB (inclusive herdada no meio familiar) e via movimento estudantil secundarista. No que se refere à passagem por diferentes "organizações", a maior parte deles seguiu um trajeto comum, com destaque às vinculações ao PCB, "Brancaleones", Var-Palmares, MDB, PDT e PT. Vindos de outros municípios do RS (como Cachoeira do Sul e Santa Maria), eles se deslocaram, por diferentes motivos, para Porto Alegre e estudaram na escola pública Júlio de Castilhos. O "Julinho", como é conhecido, funcionava, em 1966, "como uma célula comunista em qualquer lugar do mundo, segundo o figurino do 'partido de novo tipo' idealizado por Vladimir Lênin no início do século" (Guterrez, 1990, p.30).

Vários eventos foram referidos como singulares das mobilizações estudantis ocorridas durante o ano de 1967 e início de 68. Dentre as razões que teriam os desencadeado são citadas: a morte do estudante Edson Luís no Rio de Janeiro e as mobilizações que gerou; o acordo do MEC com a agência governamental norte-americana USAID que vislumbraria uma reforma no ensino abandonando o "padrão europeu" (estrutura educacional fundada no modelo "clássico" ou "científico", ensino público 
gratuito, etc.); as decisões do "governo militar" de reduzir os recursos para o ensino médio e universitário; a falta de vagas para alunos que haviam passado no vestibular; a proibição do funcionamento do DCE da UFRGS; no "Julinho" os alunos se insurgem "contra as normas restritivas" impostas pela direção que proibira o uso de "cabelos compridos" para os homens e de "minissaias" para as mulheres. Por conta dos protestos empregados, o Grêmio do colégio fora fechado e os alunos decidiram reativá-lo "numa barraca na praça em frente ao colégio" (Gutierrez, 1999, p. 32-34).

As "manifestações estudantis" repercutiram igualmente nas tomadas de posição frente ao PC que, nessa conjuntura, não estaria correspondendo às aspirações e inspirações revolucionárias dos adeptos. O VI Congresso do partido ocorrido nesse ano teria sido o marco do rompimento das "bases estudantis" que constituíram "dissidências" em vários estados.

Havia dissidentes universitários e secundaristas. Os primeiros assumiram ou afirmaram-se no comando da "Dissidência". Portanto, mais que uma ação de rompimento, a "dissidência do PC" acabou afirmando-se mesmo como uma "organização", ainda que provisória, a ponto de produzir sua própria "dissidência" (por expulsão ou rompimento, conforme diferentes versões). Nesta encontram-se os "secundaristas", particularmente os "Brancaleones", que acabaram sendo chamados "dissidentes" da "dissidência", mas não deixavam, obviamente, de serem "dissidentes" do PCB.

Os motivos assumidos da divisão teriam sido a defesa da articulação imediata da "guerrilha rural" ou do "foquismo" e a oposição dos "Brancaleones" à aproximação feita com uma parcela de militantes "dissidentes" da Polop (localizados basicamente em Minas Gerais). Porém, observa-se que sob as disputas mais "programáticas" havia diferenças de disposições, de "gerações" e de redes de relações que se traduzia também em "estilos de atuação" e em "rótulos".

Em fevereiro de 1968, os "Brancaleones" participaram da direção da União Gaúcha dos Estudantes Secundaristas (UGES) presidida por Luis Andréa Fávero, o que o que teria lhes permitido inscrever-se em mobilizações estudantis "mundiais" ocorridas naquele ano, reivindicando o "papel histórico" para a "juventude" e, por este intermédio, buscando o reconhecimento do seu próprio "papel".

As atividades e eventos promovidos a partir da inserção na UGES, durante o ano de 1968, são vistas, no momento em que foi examinado o conjunto de relatos reunidos, como desprovidas do impacto "revolu- 
cionário" almejado e ao movimento estudantil é imputado um arrefecimento que instigava os militantes a buscarem formas mais contundentes de atuação. Adiciona-se a isso que, a promulgação do Ato Institucional número 5 no final do ano, a um só golpe ratificava o "fechamento político" do regime com disponibilidade para uso dos mecanismos necessários para manter-se, reforçando, para alguns militantes, a adoção da via clandestina e armada como única opção plausível e eficaz.

Para os "Brancaleones", o ano de 1969 foi marcado por redefinições "organizacionais" que resultaram na sua relativa dispersão, ao menos em termos de lugares a partir dos quais desenvolviam suas intervenções. Sendo necessário frisar que, mesmo sendo eventualmente diferentes, as "organizações" as quais adentravam tinham sempre a característica de privilegiar as "ações armadas" na "luta contra a ditadura".

A conexão mais decisiva para o "grupo" se deu a partir da liderança de Carlos Araújo, um advogado trabalhista, com forte inserção sindical, que fora, desde a década de cinquenta, ligado ao PCB (assim como seu pai e irmãos que tinham a mesma formação e atuação profissional e política). Com trânsito nacional significativo, ele reuniu militantes provenientes de diferentes meios, sendo que a característica mais comum entre eles é a detenção ou reivindicação de uma origem "operária" ou nas "classes trabalhadoras". Interessante que Araújo acabou promovendo a reunião dos "dissidentes" secundaristas do PC com a outra parcela dos "dissidentes" da Polop de Minas Gerais que não participaram da fundação do POC ("organização" fundada pelos "dissidentes" universitários do PC gaúcho com uma parcela de "dissidentes" da Polop de Minas, a qual os "Brancaleones" teriam se oposto, como foi anteriormente dito).

O porta-voz do OP ora referido, passava a atuar na organização clandestina Vanguarda Popular Revolucionária (VPR), inclusive participando do seu "campo de treinamento militar" no Vale da Ribeira, para onde foi em detrimento da faculdade de geologia que iniciara em 1969. No seu retorno, foi preso, "trocado pelo embaixador Suíço" (sequestrado com o objetivo de libertação de "presos políticos") e "banido" para o Chile. Depois teria ido para Cuba fazer "treinamento". De volta a Santiago (Chile), militou na "clandestinidade" sob a ditadura de Pinochet. Por fim, terminou o período de exílio em Cuba, lá residindo até o final de 1977.

Tendo morado naquele país e realizado viagens pela Europa (principalmente França), Ubiratan privilegia, na sua reconstrução biográfica, a 
ênfase no gosto pelas expressões culturais (literatura, cinema, teatro, etc.), a participação em grupos de discussão do marxismo com a esposa chilena (igualmente militante) e as "experiências coletivas" da "realidade cubana".

A ideia de "coletividade" aparece na descrição dos seus movimentos, sempre buscando demonstrar o apoio e a influência do mesmo círculo de amizades ao longo do tempo. Talvez beneficiado pelo fato de ter um irmão deputado estadual, um dos principais protagonistas gaúchos da reconstrução do PDT e reconhecido por pertencer à "ala de esquerda" do partido, o que, inclusive, se refletiu na maior aproximação do entrevistado com Carlos Araújo nos anos 1980, enquanto esteve filiado ao PDT.

Dentre os fatores decisivos no seu itinerário está o deslocamento para o PT no momento de ascensão dessa sigla e no momento de declínio do PDT (deslocamento feito por praticamente todos os membros dos "brancaleones") e a administração de laços com contemporâneos da contestação ao "regime militar". Formado em economia pela UFRGS já no período de redemocratização, em 1990 começou a militar no núcleo dos economistas do PT. Em 1992, como coordenador desse núcleo, desenvolveu o programa de gestão e finanças públicas e, em 1993, foi convidado por Tarso Genro (que fora líder de um dos "grupos" de resistência à ditadura militar no estado) para ser o Secretário do Gabinete de Planejamento de Porto Alegre e, consequentemente, para coordenar o Orçamento Participativo na capital. Nesse cargo ele ficou até 1998 e, com a conquista do governo do estado pelo PT, coordenou o Gabinete de Planejamento do Orçamento Participativo (OP), de 1999 a 2002, no governo de Olívio Dutra. Nesse ano concorreu, sem sucesso, à deputação estadual, amparado pela coordenação da experiência do Orçamento Participativo.

A partir de então passou a atuar como assessor do deputado estadual e ex-prefeito de Porto Alegre, Raul Pont. Vinculou-se também à tendência do PT denominada "Democracia Socialista", que tem como um dos seus fundadores e principais líderes o próprio Raul Pont (que fora militante do Partido Operário Comunista, do Iepes, do Setor Jovem e da Tendência Socialista do MDB).

Como se vê, a migração para o PT, a atualização de vínculos com antigas lideranças da contestação ao regime militar e o investimento na obtenção de um título escolar de economista, associados à biografia militante, permitiram a conquista de uma posição destacada na hierarquia de cargos disponíveis para os militantes. 
Ubiratan de Souza acabou se constituindo como um dos principais porta-vozes da "causa" ou "bandeira" da "participação popular", viabilizada pelo Orçamento Participativo (OP). Publicou desde artigos de circulação interna ao partido, até matérias em jornais internacionais (principalmente por ocasião dos Fóruns Sociais Mundiais realizados em Porto Alegre). Produziu um livro sobre o OP em coautoria com Tarso Genro, intitulado "Orçamento Participativo: a experiência de Porto Alegre".

Para finalizar, cabem dois registros: um que aponta para a escolha da formação universitária concebida como parte de uma "vocação" para intervenção e o outro que informa o elo que procura estabelecer entre as condições inaugurais de militância e o significado atribuído ao OP:

[...] Porque pela minha militância política e pelo estudo do Marx, do Capital, a economia política para mim interessava. Essa era a minha vocação mesmo [...]. (Entrevista com Ubiratan de Souza)

[...] Esse é o grande avanço de uma experiência de esquerda que estava só na clandestinidade (que não tinha liberdade nem de organização) chegar à plenitude do processo democrático com a luta das diretas. A eleição para presidente, eleição para governador, para prefeito de capitais e, depois, ser protagonista de uma experiência que vai além da democracia representativa, a democracia direta. $\mathrm{E}$ a democracia direta ela cria também um tensionamento para qualificação da democracia representativa. (Entrevista com Ubiratan de Souza)

Em um texto escrito por Ubiratan de Souza com o objetivo manifesto de propagar os "ensinamentos", "princípios" e possibilidades de "avanços" desse modelo de "gestão participativa", o OP é apresentado como uma "experiência revolucionária" e um "instrumento privilegiado de distribuição de renda pública, da democratização da gestão do Estado e de construção da cidadania". Os fragmentos abaixo permitem cotejar as diferentes formas de apresentar os mecanismos de "participação popular".

Sobre o significado para a "esquerda" e para o "socialismo" enfatiza:

O OP é um processo de democracia direta, voluntária e universal, onde a população pode discutir e decidir sobre o orçamento público e as políticas públicas. O cidadão não encerra sua participação no ato de votar na escolha do executivo e do parlamento, mas vai muito além, decidindo e controlando a gestão pública. [...] A nossa experiência do OP, também, aponta o caminho para a superação, de maneira contemporânea, da crise do socialismo 
burocrático, respondendo de maneira criativa e original à principal questão política da decadência e da derrocada do Leste Europeu, ou seja, a relação autocrática do estado com a sociedade. (http://www.partehartuz.org/textos_programas_03-04/ubiratan.pdf, p. 1)

E sobre a base legal que garantiria a "vontade política e autonomia", sublinha que:

O orçamento público está previsto nas Constituições federal (Art. 165, III) e Estadual - RS (Art. 149, III) e nas leis orgânicas municipais como uma lei de iniciativa do executivo. Também, a Constituição Federal em seu artigo $1^{\circ}$, parágrafo único, diz - "Todo o poder emana do povo, que o exerce por meio de representantes ou diretamente, nos termos desta Constituição" e no artigo $5^{\circ}$, inciso XVI, estabelece o 'direito de reunião' e inciso XXXIV o 'direito de petição ao Poderes Públicos' do povo brasileiro. Ademais, a nova Lei de Responsabilidade Fiscal (maio/2000), no parágrafo único do art. 48 diz: 'A transparência será assegurada mediante incentivo à participação popular e realização de audiências públicas, durante os processos de elaboração e discussão dos planos, lei de diretrizes orçamentárias e orçamentos. (http:// www.partehartuz.org/textos_programas_03-04/ubiratan.pdf, p. 2)

A segunda liderança, João Ribeiro, se define como poeta, compositor, advogado e militante político. Nascido em São Luís na década de 1950, o seu pai era embarcadiço e foi vigia noturno, sua mãe era operária de uma fábrica têxtil e a família possuía uma forte adesão religiosa, o que se refletiu na sua experiência como coroinha de uma igreja católica. A estreia na intervenção política se deu na década de 1970, quando atuou no movimento estudantil universitário e realizava o curso de Engenharia Mecânica na atual Universidade Federal do Maranhão. A militância política teria influenciado no abandono da universidade (também iniciou o curso de economia no início dos anos 1980, sem concluí-lo). Participou do movimento estudantil de São Luís na década de 1970 e foi uma das principais lideranças da "greve pela meia passagem" de 1979, evento reconhecidamente marcante do período no estado e sobre o qual é constantemente chamado a falar, graças, principalmente, à notoriedade posteriormente conquistada. Nesse período, esteve em contato com dirigentes da Organização Revolucionária Marxista-Política Operária (Polop), numa seção de Recife (PE), mas sem participar de "ações armadas". Em entrevista a um jornal alternativo que reúne militantes de esquerda de 
São Luís, ele aponta que "o ano de 1979 foi o ‘68' da minha geração” e combina eventos mais nacionais com os aqueles mais locais:

Ano de uma imensa efervescência política e cultural no Maranhão e no Brasil, de lutas operárias e camponesas, dos movimentos contra a carestia, das jornadas de cinema Super-8, dos festivais universitários de música e poesia, da volta dos exilados e anistia aos presos políticos, do Congresso de Reconstrução da UNE e da Greve da Meia Passagem. Nem preciso mais dizer o que significou a Greve de 79, pois a partir daí veio a reforma partidária, a fundação do PT e a inserção de variados atores na cena política brasileira. (Vias de Fato, p. 6, fevereiro de 2010 )

Na mesma ocasião, João Ribeiro declara que a única herança política da família foi a prisão de tios durante a intentona comunista, que teria sido um "segredo de família" que lhe despertava "curiosidade" e "fascinação" (idem), ao passo que a influência musical é mais detalhadamente reconstituída:

meu avô por parte de mãe [...] era motorneiro de bonde, grande boêmio, tocador de violão [...] minha avó [...], mãe da minha mãe, que não cheguei a conhecer, era neta de escravos e tocava piano. Meu pai [...] gostava de cantarolar canções de Vicente Celestino, Orlando Silva, Carlos Galhardo e ouvia muito rádio, também escrevia algumas coisinhas literárias [...]. Somem-se a isso as radiolas da zona que tocavam o dia inteiro próximo ao casarão em que residia.

Em 1986 foi aprovado no concurso da Receita Federal para Técnico do Tesouro Nacional (Analista Tributário). Funcionário Público Federal de carreira, formou-se em Direito já na década de 1990, tendo feito Pós-Graduação em Direito Civil e Processual Civil (trabalhou com a temática dos direitos autorais, propriedade intelectual), tendo atuado como professor no curso de Direito de uma faculdade privada na capital.

Em 1993, organizou o I Seminário Maranhense de Direitos Autorais. Foi fundador do Sindicato dos Servidores Públicos Federal, atuou no Sindicato dos Professores da rede particular de ensino e prestou assessoria ao Sindicato dos Artistas. Também fez parte do Comitê Brasileiro pela Anistia. É fundador o PT, do qual chegou a ser presidente do diretório municipal, em 1996, ano em que concorreu à vereança em São Luís por este partido com o slogan "artista-militante", ficando na suplência. Presidiu a Fundação Municipal de Cultura (FUNC), entre 1997 e 1998, e foi secretário estadual de cultura (2007-2009). Em ambos os casos, trata- 
ram-se de governos encabeçados pela liderança do PDT, Jackson Lago, primeiro na prefeitura da capital, São Luís (1997-2000), e, depois, no governo do estado (2007-2009).

Um dos momentos mais grifados pelos militantes que acompanharam de alguma forma o trajeto em exame, e do próprio agente, como de conquistas culturais e políticas do estado foi a realização do I Fórum Municipal de Cultura de São Luís, em 1997, durante a presidência de João Ribeiro na FUNC, na qual, segundo o próprio, chegou "praticamente carregado nos braços pelo movimento cultural". De fato, ele acaba se afirmando como o ego de uma rede de militantes que encontram nesta entrada as condições de emergência de um "modelo coletivo", construído na conexão entre uma série de instâncias de formulação, de referencias de identificação e de parâmetros de atuação que constituem o repertório de confronto agilizado. Assim, as interpretações retrospectivas acerca dos objetivos para a realização do primeiro Fórum Municipal de São Luís e das justificativas para o investimento nesse tipo de modalidade de intervenção aparecem atreladas ao imperativo da "participação popular" e da inscrição da "sociedade civil" na arena pública de discussão. Ambas, que se exercem mediante a prática do debate e da discussão, ora aparecem como sinônimas e ora como tipos complementares de dois níveis distintos de atuação, levadas a cabo por indivíduos com relações "militantes" e "competentes" (em termos de especialização, de dedicação e de extração social) distintas com as problemáticas priorizadas.

A conquista por Jackson Lago do governo estadual em 2007 e a escolha de João Ribeiro para ocupar a pasta da cultura foi a oportunidade de agentes que investiam na posição de porta-vozes da "cultura" de ativar ideias de políticas culturais que vinham sendo construídas, de exercer cargos relativamente melhor alocados no âmbito político (para alguns garantindo, inclusive, a sua subsistência econômica) e, por esse intermédio, de disputar posições e posicionamentos com lideranças estabelecidas no espaço político e cultural do estado. O pessoal político-administrativo que constituiu a secretaria de cultura estaria respaldado pelo passado de experiências de "participação" constantemente acionadas dos discursos de apresentação/justificação da "equipe". No discurso desses militantes a dimensão cultural aparece como elemento chave de um projeto de transformação social e político e, principalmente, passível de ser conduzido por protagonistas cuja atuação conjunta e contínua, desde os fóruns de 
cultura, se reproduzia no âmbito político-administrativo, legitimando sua constituição como "equipe de governo".

No "plano de governo" concebido para ser executado entre os anos de 2007 a 2010, período que se supunha durar a gestão do petista à frente da SECMA sob o Governo de Jackson Lago do PDT, são estabelecidas as diretrizes da gestão. Com o slogan: "A imaginação a serviço da cidadania e do desenvolvimento", são explicitadas as "quatro grandes diretrizes" da gestão:

1. Democratização da cultura como mecanismo de socialização dos bens e serviços culturais e garantia dos direitos inerentes à cidadania;

2. A cultura como questão estratégica para a construção de políticas públicas de desenvolvimento sustentável do Maranhão;

3. Fortalecimento da identidade cultural maranhense (maranhensidade), valorizando a diversidade do patrimônio cultural material e imaterial, bem como promovendo a inovação criativa e intercâmbios culturais;

4. Implementação de política de gestão cultural democrática e descentralizada, que integre os agentes culturais e garanta a participação popular. (Plano Estadual da Cultura do Maranhão, 2007-2010, p. 11).

Cabe ressaltar a ideia de "maranhensidade" que a administração procurou imprimir às e nas atividades e eventos conduzidos, como marca de uma identidade da sua gestão com o "povo maranhense", cumplicidade fundada numa espécie de estilo de vida e símbolos de distinção, ao mesmo tempo "existentes" e "ideais". O fragmento abaixo permite evidenciar a tentativa de abarcar, com a mesma ideia, o conjunto de elementos frequentemente acionados para definir a "cultura maranhense" (e não raro, suas "tradições") combinando-os a categorias que remetem aos valores do mundo "democrático", visando objetivos ou princípios morais e universais.

"Maranhensidade é carnaval e academia; são joão e literatura; educação e cultura; turismo e tecnologia; intercâmbio e identidade; pertencimento e trocas; tolerância e diversidade; música e magia; conhecimento e universalidades; saberes e fazeres; direitos e liberdade para exercê-los: à livre expressão e manifestação artística, jornalística, do pensamento; enfim, do engenho e arte daquilo que temos de melhor para contribuir com a cultura da paz e com o reencantamento da Humanidade" (João Ribeiro, "Maranhensidade: um estado de alegria", Jornal Pequeno, 14 de janeiro de 2008).

A agilização de tais aspectos é compatível com a defesa de estratégias de "descentralização da cultura" que implicou numa modificação 
das estruturas de organização e financiamento das principais "festas populares" (carnaval e são joão, então nomeadas "carnaval da maranhensidade" e "são joão da maranhensidade") do estado. Consequentemente, estabelecendo oposições com as prioridades dadas até então (pelos governos e gestores anteriores) e fixando uma série de embates entre artistas, jornalistas e produtores culturais.

$\mathrm{Na}$ "missão" da secretaria, redefinida em relação àquela explicitada nos relatórios das gestões anteriores, ${ }^{6}$ a ênfase recai na produção de políticas públicas para a cultura orientada por registros comuns à retórica democrática e, especialmente, a determinadas vertentes partidárias de esquerda, ${ }^{7}$ tais como as ideia de "princípios éticos", "cidadania" e "transformação social".

[...] formular e executar políticas públicas fundamentadas em princípios éticos e democráticos, promovendo o fomento, a valorização, a preservação, o registro e a difusão dos bens e serviços culturais, de modo a fortalecer a cidadania e a identidade maranhense'. Ao assumir para si esta missão, a Secretaria de Estado da Cultura parte do princípio de que as políticas a serem desenvolvidas precisam primar por ações pautadas em princípios éticos e democráticos que possam contribuir de forma definitiva para as grandes transformações sociais a partir do reconhecimento de cada cidadão e cidadã como produtor e beneficiário da cultura, e da valorização e vivificação das diversas manifestações culturais maranhenses (Plano Estadual de Cultura do Maranhão, p. 15, 2007).

A rápida duração da administração de João Ribeiro inviabilizou, para o momento, uma análise mais aprofundada dos seus investimentos efetivos nas políticas de cultura (por exemplo, não se teve acesso ao relatório das atividades desempenhadas pela Secma). Todavia, mediante a análise dos depoimentos coletados, é possível indicar algumas nuances importantes do receituário que informa a produção de políticas públicas

6 No Relatório de Atividades da Secretaria de Estado da Cultura referente ao governo anterior, do ano de 2006 e elaborado pela Assessoria de Planejamento e Ações Estratégias (Asplan) a "Missão Institucional" da Secma é definida da forma que segue: "Órgão responsável pela elaboração e execução da política pública de natureza cultural, operando na perspectiva da ação transformadora da sociedade, estimulando o exercício da cidadania e o aprimoramento estético dos seus membros, sempre pautada na preservação e difusão dos bens culturais materiais e imateriais do Maranhão".

7 Como aquela observada no "discurso petista" sobre a "participação popular" (Reis, 2008). 
consideradas eficazes e os espaços privilegiados (como "fóruns" e "conselhos") nos quais agentes interessados (sejam "gestores", a "sociedade civil", ou o "cidadão comum") tomam a palavra, discutem e debatem sobre questões "lhes dizem respeito". Para os agentes estudados esse quadro, no entanto, somente se completa com o estabelecimento de um corte antagônico fundamental com o que seria uma lógica arraigada de favorecimentos pessoais na gestão da cultura (de "apadrinhamento", "troca de favores", "falta de transparência", "patrimonialismo"...) e, ao mesmo tempo, de um possível mecanismo de superação centrada na realização de editais. Interessante sublinhar que essa dicotomia é fixada e direcionada não somente aos opositores externos como também para apontar "falhas" na prática dos próprios membros do meio interno de relações.

Sob os registros da denunciação e/ou da justificação, acionados de forma mais ou menos direta ou implícita, atenta-se para o constante processo de redefinição da lógica faccional, impulsionada e impulsionadora de uma dinâmica animada pelos interconhecimentos (Fabiani, 2003). A ativação de uma gramática tida como impessoal e universalizante de execução de ações públicas, como é o caso da defesa dos editais, se transforma em mecanismos de administração de reputações e, notadamente, de desqualificações pessoais. Desqualificações essas que podem ter como alvo tanto adversários históricos como aliados de outrora, e até mesmo serem utilizadas nas lutas internas à facção com vistas a redefinir clivagens, refazer alianças, reagir a supostas ingratidões e retaliar possíveis expectativas frustradas. Como indicou Moacir Palmeira (2006, p. 144), a plasticidade do "modelo faccional", assim como para todos os referenciais dominantes (referidos ou não às políticas públicas) viabiliza sua adequação, por incorporação e neutralização, de "iniciativas de mudança das práticas políticas”.

\section{Considerações finais}

A reflexão realizada objetivou demonstrar que, no que pese haver um relativo "acordo" acerca das condutas e temáticas basilares que constituem o repertório de mobilização democrática, estas somente podem ser apreendidas levando-se em conta as condições específicas de seus usos, acionados por agentes portadores de determinadas características sociais, orientados por determinadas matrizes de referenciais adquiridas e construídas nas suas variadas inserções. Essas dimensões revelam processos mais ou menos eficazes e conflitivos de objetivação e institucio- 
nalização de problemáticas políticas tidas como legítimas e seus porta-vozes autorizados em dados contextos (nacionais ou regionais).

Logo, tais fatores são primordiais para a compreensão de modelos de gestão pública como o resultado de disputas entre agentes, enredados em relações objetivas, que se movimentam e posicionam-se uns em relação aos outros. E, nestas condições, lançam mão de "estratégias individuais ou coletivas, espontâneas ou organizadas, que visam a conservar, transformar, transformar para conservar ou, até mesmo, conservar para transformar" (Bourdieu, p.175, 1998).

Assim, o OP e as "políticas para a cultura" são produzidos nas ações e reações, atrações e repulsas, escolhas e exclusões daqueles e entre aqueles com disposições, cauções e oportunidades de entrar no jogo democrático e garantir seu lugar no ranking das suas lideranças.

Os desdobramentos da discussão focada nos agentes, discursos e clivagens revelam o entrecruzamento de lógicas e princípios de estruturação do espaço político no Rio Grande do Sul e no Maranhão. Porém, no primeiro caso, observou-se, mediante o exame dos itinerários de militância e de condições de atuação no cenário político "gaúcho", a viabilização da afirmação institucional de lideranças com perfis políticos "favoráveis" à adesão a bandeiras como aquela da "participação popular" e sua operacionalização relativamente eficaz. Ao passo que, no Maranhão, os usos de uma "gramática democrática" vêm perpassados ou são defrontados com o peso das rivalidades faccionais e da hierarquização do universo político.

Neste segundo contexto, a ativação de um repertório de expressões e simbologias que remetem ao ideal de "participação" e "democratização" se dá por intermédio de "porta-vozes" situados em posições dominadas no espaço social e político mais amplo, cujos movimentos se inscrevem simultaneamente nas regras de um jogo oligárquico (Elias, 1999) e se justificam no esforço em negá-lo ou contestá-lo. Ao privilegiarem a "arena" das disputas em torno das "políticas públicas" para a "cultura" e ao reivindicarem a condição de intérpretes ou mediadores do "popular" reforçam, de certo modo, um conjunto de oposições ou de imposições que envolvem desequilíbrios da balança do poder no estado. Do mesmo modo, quando lançam mão desses "valores democráticos" como antídotos às práticas tidas como "tradicionais" ou "atrasadas" revelam as ambivalências decorrentes dessa posição dominada no espectro de forças políticas e da capacidade de renovação dos segmentos ("famílias", "gru- 
pos", "setores", "interesses") dominantes. Logo, expõem de forma transparente os obstáculos para afirmação dos próprios "ideais democráticos" que professam nessas circunstâncias. O que não significa desconsiderar que a existência, mesmo frágil, de discursos e "experiências", como aos aqui analisados, possa fazer emergir novas identidades, lugares e formas de expressão políticas. Sem deixar de mencionar o potencial que os mesmos trazem para tornar mais "complexo o 'trabalho de dominação' dos dominadores tradicionais" (Palmeira, 2006, p. 148).

\section{Referências}

ARRETCHE, M. Dossiê agenda de pesquisa em políticas públicas (Apresentação). In: RBCS, vol. 18, n. 51, p. 7-9, fevereiro, 2003.

AVRITZER, L.; NAVARRO, Z. A inovação democrática no Brasil. São Paulo: Editora Cortez, 2003.

AVRITZER, L. Um desenho institucional para o novo associativismo. In: Lua Nova. n. 39, p. 148-174, 1997.

BOURDIEU, P. Classificação, desclassificação, reclassificação. In: NOGUEIRA, M. A.; CATANI, A. Pierre Bourdieu. Escritos de educação. Petrópolis, RJ: Vozes, 1998.

BRAUD, P. Le jardin des délices démocratiques. Paris: Presses de la Fondation nationale des Sciences Sociales, 1992.

. Sciene Politique. 1. La Démocratie. Paris: Éditions du Seuil,1997.

CORADINI, O. L. "Politização de interesses através de frentes parlamentares". Tomo, n. 1 (1998)m NPPCS/UFS, n. 13 jul./dez., 2008.

. Escolarização, militantismo e mecanismos de "participação" política.

In: Heredia, B. et al, (Org.) Como se fazem eleições no Brasil. Rio de Janeiro: Relumé Dumará, 2002.

DOBRY, M. "Les transitions démocratiques: regards sur l'etat de la 'transitologie", Revue Française de Science Politique, 50 (4-5), p. 579-614, agosto-outubro, 2000.

ELIAS, N. Introdução à sociologia. Portugal: Edições 70, 1999.

FABIANI, J-L. A Córsega ou as servidões da autenticidade. In: Revista Sociologias. Porto Alegre, ano 5, n. 9, p. 354-368, jan/jun, 2003.

FIUZA, A. Teoria e Debate. Revista Bimestral da Fundação Perseu Abramo ano 18, n. 6. fev/mar 2005.

FONTES, V. M. Démocratie et Révolution: Sciences Sociales et pensée politique ao Brésil contemporain. Paris, Tese de doutorado, Universidade de Paris X, 1996.

GANDIN, D. A prática do planejamento participativo. Petrópolis: Vozes, 1994. 
GILCHER-HOLTEY, I. "Quand les phrases interdites descendaient dans la rue: mouvements sociaux et internationalisation- l'exemple de Mai 68". In: SAPIRO, G. (dir.). L'espace intellectuel en Europe. De la formation des États-nations à la mondialisation (xix-xxi siècle). Paris: La Découverte, 2009.

GRILL, I. G.; REIS, E. T. dos. Entre Togados e Votados: as 'batalhas jurídicas' nas disputas eleitorais. Paper apresentado no $7^{\circ}$ Encontro da ABCP, Recife, 2010.

GRILL, I. G. Os usos dos ismos em batalhas políticas e intelectuais (MA e RS). $34^{\circ}$ Encontro Anual da Anpocs, Caxambu, 2010.

. Heranças políticas no Rio Grande do Sul. São Luís: EDUFMA, 2008.

GUILHOT, N. Os profissionais da democracia em ação. In: LINS, D.; WACQUANT, L. (Org.). Repensar os Estados Unidos: por uma sociologia do superpoder. Editora Papirus, 2003.

GUTIÉRREZ, C. W. A Guerrilha Brancaleone. Porto Alegre: Proletra, 1999.

LACLAU, E. "Más allá de la emancipación"; "Universalismo, particularismo y la cuestión de la identidad". In.: Emancipación y Diferencia. Buenos Aires: Ariel, 1996.

LANDÉ, C. H. Introduction: the dyadic basis of clientelism. In: SCHMIDT, S.W. et alli. (Eds.). Friends, Followers and Factions. A Reader in political clientelism. Berkeley, University of California Press, 1977.

MAYER, A. C. "A importância dos 'quase-grupos' no estudo das sociedades complexas". In: FELDMAN-BIANCO, B. Antropologia das sociedades contemporâneas. S.P: Global, 1987.

MEMMI, D. L'Engagement politique. In: GRAWITZ, M.; LECA, J. (dir.). Traité de Science Politique; v. 3: L'Action politique. Paris, PUF, 1985.

MOUFFE, C. The Democratic Paradox. London: Verso - 2000.

MOURA, J. T. V.; SILVA, M. K. Atores sociais em espaços de ampliação da democracia: as redes sociais em perspectiva. Revista de Sociologia e Política, v. 16, p. 43-54, 2008.

NONJON, M. "Professionnels de la participation: savoir gérer son image militante". Politix, n. 70, p. 89 -112, 2005/2.

OFFERLÉ, M. Sociologie des organisations patronales. Paris: La Découverte, 2009.

Gallimard, 1993.

PALMEIRA, M. Eleição Municipal, Política e Cidadania. In: PALMEIRA, M.; BARREIRA, C. (Org.). Política no Brasil. Visões de antropólogos. Cap. 5. Rio de Janeiro: Relume Dumará: NUAP/UFRJ, p. 137-150, 2006.

PÉCAUT, D. Os intelectuais e a política no Brasil, entre o povo e a nação. São Paulo: Ática, 1990. 
REIS, E. T. dos. "Em nome da 'cultura': porta-vozes, mediação e referenciais de políticas públicas no Maranhão". Revista Sociedade e Estado, v. 25, n. 3, Brasília, set./dez. 2010.

. "Em nome da participação popular: constituição de uma causa legítima e disputas por sua definição no Rio Grande do Sul". Revista Pós Ciências Sociais (UFMA), v. 9/10, p. 105-132, 2008a.

. Da Contestação à Profissionalização Política: capital social, capital militante e capital político. In: GRILL, I. G.; REIS, E. T.; FILHO, J. B. (Org.). Elites, profissionais e Lideranças Políticas: pesquisas recentes. São Luís: Editora da UFMA, 2008b.

. A "arte" da intervenção política: origens sociais, carreiras e destinos de militantes que lutaram contra a ditadura. In: CORADINI, O. L. (Org.). Estudo de Grupos Dirigentes no Rio Grande do Sul: algumas contribuições recentes. Porto Alegre: Editora da UFRGS, p. 43-60, 2008c.

. Contestação, Engajamento e Militantismo: da 'luta contra a ditadura' à diversificação das modalidades de intervenção política no Rio Grande do Sul. Tese de Doutorado defendida junto PPG-CP/UFRGS, 2007.

WEBER, Max. "A política como vocação". Ciência e Política: duas vocações. São Paulo: Cultrix, 1993. 